ORIGINAL ARTICLE

\title{
Hospital admissions for human T-cell lymphotropic virus type-1 (HTLV-1) associated diseases in Dominica
}

\author{
O Adedayo, G Grell, P Bellot
}

See end of article for

authors' affiliations

Postgrad Med J 2003;79:341-344

Correspondence to:

Dr Olayinka Adedayo,

Department of Internal

Medicine, Bronx Lebanon

Hospital, 1650 Selwyn

Avenue Apt 15A, Bronx

NY 10457, USA

oadedayo@hotmail.com

Submitted

24 January 2002

Accepted

17 December 2002

Human T-cell lymphotropic virus type 1 (HTLV-1) is a retrovirus that is endemic in certain regions of the world, and may account for significant morbidity and mortality among hospitalised patients.

Sixty six HTLV-1 seropositive patients admitted to hospital with HTLV-1 associated diseases from 1995-99 were studied. HTLV-1 screening was done with ELISA and confirmed on western blot testing. There were 32 females $(48.5 \%)$ and 34 males $(51.5 \%)$. The mean age was 56 years and the age range was $9-89$ years.

The main associated diseases were tropical spastic paraparesis or HTLV-1 associated myelopathy in $18.2 \%$ of cases, acute form of adult T-cell leukaemia/lymphoma $7.6 \%$, lymphomas $15.2 \%$, and ectoparasites/endoparasites in $40.9 \%$. HTLV-1 is associated with diseases in Dominica and association with severe forms of strongyloidiasis and scabies is particularly noted.

$\mathrm{H}$ uman T-cell lymphotropic virus type 1 (HTLV-1) is a type C RNA retrovirus isolated in 1980 by Poiesz et al. ${ }^{1}$ The global prevalence may be up to $11-20$ million but it is highly endemic in certain areas of the world. ${ }^{2}$ In some parts of Southern Japan, prevalence may be as high as $30 \%,{ }^{3}$ and $2 \%-6 \%$ in some islands of the Caribbean, ${ }^{4}$ while endemic foci are also described in some south eastern states of America, Latin America, and in Central Africa. The diseases associated with HTLV-1 infection in this areas include adult T-cell leukaemia/lymphoma (ATLL), ${ }^{5}$ tropical spastic paraparesis/ HTLV-1 associated myelopathy (TSP/HAM), ${ }^{67}$ uveitis, ${ }^{8}$ infective dermatitis of childhood, ${ }^{9}$ polymyositis, ${ }^{10}$ Sjögren's syndrome, ${ }^{11} \quad$ polyneuropathy, ${ }^{12}$ arthropathy, ${ }^{13}$ and immunosuppression. ${ }^{14}$ The lifetime risk of developing an HTLV- 1 associated disease varies. The risk for ATLL is about 5\% if infection occurs before age 20 years, ${ }^{15}$ and that of TSP/HAM is $2 \%$ if infection occurs at any age. ${ }^{16}$ The risk of developing other associated diseases is unknown. We have documented diseases associated with HTLV-1 infection in the medical ward at the Princess Margaret Hospital, Dominica.

\section{PATIENTS AND METHODS}

A total of 298 inpatients in the medical wards of Princess Margaret Hospital, Commonwealth of Dominica suspected of having HTLV-1 associated diseases were screened for HTLV-1 using an enzyme linked immunosorbent assay (ELISA) technique between 1995 and 1999. Princess Margaret Hospital is a 200 bed secondary care centre in the Windward Island of Dominica (population 75 000). The spectrum of selected diseases screened for HTLV-1 included haematological malignancies, solid organ tumours, paraparesis and neuropathies, parasitic infestations, viral, bacterial and fungal infections, connective tissue disorders, arthritis, chronic renal failure, hepatic disease and dermatoses. Patients found to be HTLV-1 seropositive by ELISA had it confirmed by western blot testing at a referral centre, and were also screened for HIV by ELISA. All HTLV-1 seropositive patients were clinically examined with particular attention to the skin, lymphoreticular, rheumatology, and neurological systems. Laboratory investigations included a full blood count with differentials, stool microscopy for parasites, electrolytes, urea, creatinine, and calcium. Chest

\begin{tabular}{|ll|}
\hline \multicolumn{2}{|l|}{$\begin{array}{l}\text { Table } 1 \\
\text { HTLV-1 } 1 \text { Mean age of patients with } \\
\text { Hassociated diseases }\end{array}$} \\
\hline Diseases & $\begin{array}{l}\text { Mean age } \\
\text { (years) }\end{array}$ \\
\hline TSP/HAM & 60 \\
Lymphomas & 46 \\
Acute ATLL & 38 \\
Hyperinfective strongyloides & 61 \\
Crusted (Norwegian) scabies & 57 \\
\hline
\end{tabular}

radiography, abdominal ultrasound, and tissue biopsy for histopathology was done as indicated.

\section{RESULTS}

\section{Sex and age}

There were 66 seropositive patients out of 298 hospitalised patients screened for HTLV-1 (22.15\%). Thirty two (48.5\%) of the patients were females and 34 (51.5\%) were males. The mean age of clinical presentation was 56 years for all diseases and were in the age range of 9-89 years. The mean age of presentation of major clinical syndromes is shown in table 1.

\section{Associated diseases}

Fifty eight patients were admitted for a single disease during the period of study, while eight patients had more than one disease. The seropositive cases included 12 cases of TSP/HAM (18.2\%), which constituted $38.7 \%$ of all paraparesis/paraplegia screened, five cases of acute ATLL (7.6\%), two cases of Hodgkin's and eight cases of non-Hodgkin's lymphoma (15.2\%),

Abbreviations: ATLL, adult T-cell leukaemia/lymphoma; ELISA, enzyme linked immunosorbent assay; HTLV-1, human T-cell lymphotropic virus type 1; TSP/HAM, tropical spastic paraparesis/HTLV-1 associated myelopathy 
Table 2 HTLV-1 associated diseases

\begin{tabular}{lll}
\hline Diseases & $\begin{array}{l}\text { No of } \\
\text { cases }\end{array}$ & $\begin{array}{l}\% \text { of HTLV-1 } \\
\text { seropositives } \\
(\mathrm{n}=66)\end{array}$ \\
\hline TSP/HAM & 12 & 18.2 \\
Neuropathies of unknown aetiology & 2 & 3.0 \\
Lymphoma & 10 & 15.2 \\
ATLL (acute) & 5 & 7.6 \\
Ectoparasites/endoparasites & 27 & 40.9 \\
Pulmonary tuberculosis & 3 & 4.5 \\
AIDS/HIV & 3 & 4.5 \\
Seronegative arthropathy & 4 & 6.1 \\
Thrombocytopenia of unknown aetiology & 2 & 3.0 \\
Others & 9 & 13.6 \\
\hline
\end{tabular}

which made up $45.4 \%$ of all lymphomas, 27 cases of ectoparasitosis and endoparasitosis (40.9\%); five cases of crusted scabies, 17 cases of hyperinfective strongyloidiasis, and two cases each of giardiasis and hookworm were seropositive.

The other seropositive cases were two patients with neuropathies of unknown aetiology $(3.0 \%)$, three cases of pulmonary tuberculosis $(4.5 \%)$, AIDS/HIV in three patients $(4.5 \%)$, seronegative arthropathy in four patients $(6.1 \%)$, and thrombocytopenia of unknown aetiology in two patients $(3.0 \%)$ (tables 2, 3, and 4). There were nine other seropositive patients made up of chronic hepatitis (1) chronic renal failure (2), carcinoma of the oesophagus (1), myeloproliferative disease (1), infective dermatitis of childhood (1), Escherichia coli hepatic abscess (1), pneumonia (1), and optic atrophy (1).

\section{HIV seropositivity}

Forty nine HTLV-1 seropositive patients were screened for HIV. There were three seropositive patients $(4.5 \%)$ of whom two had AIDS.

\section{DISCUSSION}

The retroviruses associated with diseases in man are HTLV-1, HTLV-2, HIV-1, HIV-2 and all are T-cell lymphotropic. HTLV-1 is endemic in Dominica with a seroprevalence of $2.66 \%$ in asymptomatic blood donors (in press). Altogether $22.15 \%$ of selected hospitalised patients in our study were seropositive and the main associated diseases are discussed

\section{Adult T-cell leukaemia/lymphoma}

There are four clinical variants of ATLL: acute (55\%), chronic $(20 \%)$, lymphomatous (20\%), and smouldering (5\%). ${ }^{17}$ Acute ATLL is rapidly progressive with median survival of less than six months. There is marked leucocytosis, predominantly lymphocytes with lobulated nuclei (leukaemic cells), hypercalcaemia, skin infiltration, lymphadenopathy, and hepatosplenomegaly. Five patients in our study had the acute form of ATLL.

Table 3 Prevalence of diseases

\begin{tabular}{lll}
\hline Diseases & $\begin{array}{l}\text { No of cases } \\
\text { screened } \\
(\mathbf{n = 2 9 8 )}\end{array}$ & $\begin{array}{l}\text { No }(\%) \text { of } \\
\text { HTLV-1 } \\
\text { seropositives }\end{array}$ \\
\hline $\begin{array}{l}\text { Paraparesis } \\
\text { Acute ATLL } \\
\text { Lymphomas }\end{array}$ & 31 & $12(38.7)$ \\
$\begin{array}{l}\text { Other haematological } \\
\text { malignancies }\end{array}$ & 22 & $5(100)$ \\
$\begin{array}{l}\text { Solid organ tumours } \\
\text { Parasitosis }\end{array}$ & 24 & $1(45.4)$ \\
Other infections & 66 & $1(12.5)$ \\
Other diseases & 55 & $27(40.9)$ \\
\hline
\end{tabular}

\begin{tabular}{ll|}
\hline $\begin{array}{l}\text { Table } 4 \\
\text { infestation }\end{array}$ & HTLV-1 and parasitic \\
\hline Parasites & $\begin{array}{l}\text { No }(\%) \text { of } \\
\text { cases }(\mathrm{n}=27)\end{array}$ \\
\hline $\begin{array}{l}\text { Strongyloidiasis } \\
\text { Crusted (Norwegian) }\end{array}$ & $5(186.7)$ \\
scabies & $5(18.5)$ \\
Giardiasis & $2(7.4)$ \\
Hookworm & $2(7.4)$ \\
\hline
\end{tabular}

They all presented with marked leucocytosis with atypical lymphocytes while hypercalcaemia on admission occurred in four patients as well as hepatosplenomegaly. The lymphomatous form of ATLL may present like acute ATLL but leucocytosis and atypical cells are usually absent or minimal. There were eight seropositive patients with non-Hodgkin's lymphoma in our study out of which seven can be classified as lymphomatous ATLL.

The eighth patient was a 60 year old woman who presented with well defined skin patches over her trunk and abdomen (fig 1). She was initially referred to us as a case of extensive tinea corporis, but histology of a skin biopsy specimen showed features of mycosis fungoides. She developed multiple skin nodules on the upper limb, generalised lymphadenopathy, and severe icthyosis of the lower limb four months later (figs 2 and 3). The histopathology of a skin nodule biopsy specimen showed non-Hodgkin's lymphoma. We classified her as a case of chronic ATLL, which usually has an insidious onset and natural history is more prolonged than acute and lymphomatous ATLL. We did not identify any smoldering ATLL in our study. The mean age of presentation of the acute ATLL and lymphomatous ATLL in our study (table 1 ) is consistent with the 43 years found in cases of ATLL in Jamaica, ${ }^{18}$ suggesting an early life exposure to the virus through maternal to child transmission as leukaemogenesis may take 20-40 years. ${ }^{19}$

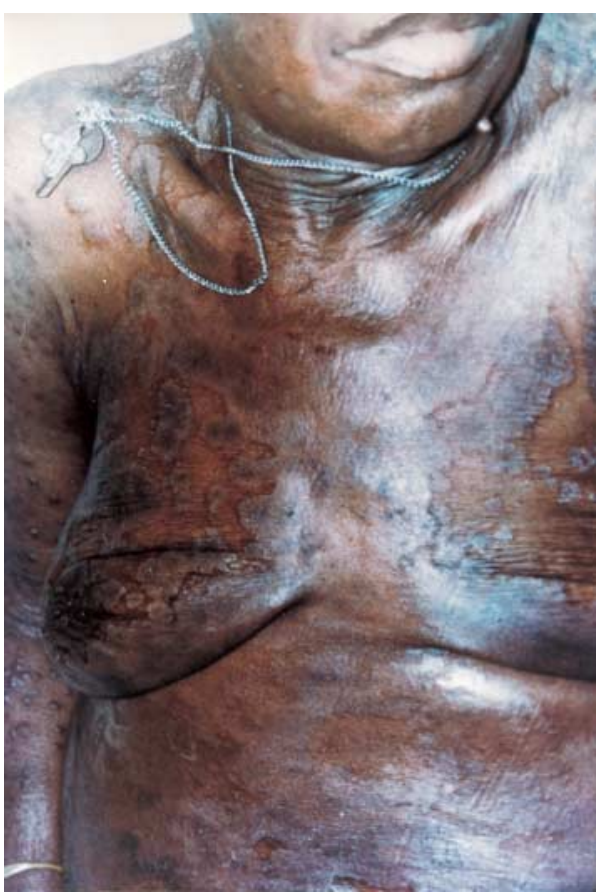

Figure 1 Extensive well demarcated patches in a 60 year old HTLV-1 seropositive woman with initial diagnosis of mycosis fungoides (all photos published with patient's permission). 


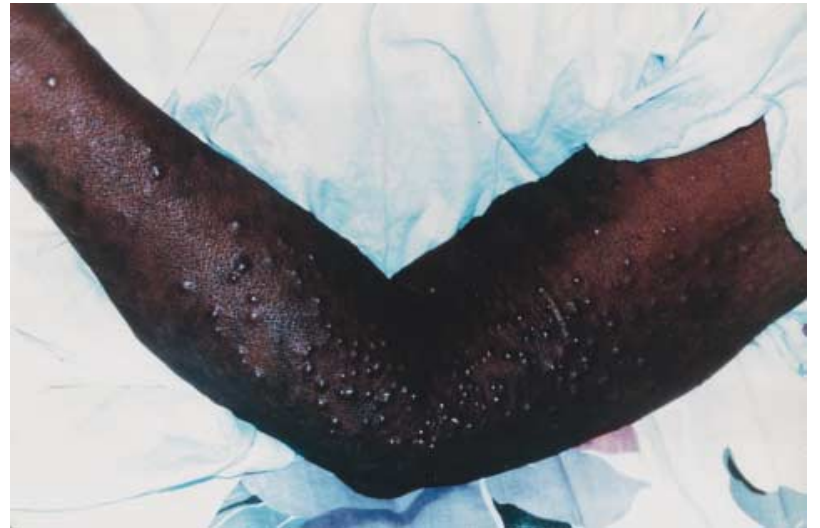

Figure 2 Multiple nodules in upper limb of same patient four months later.

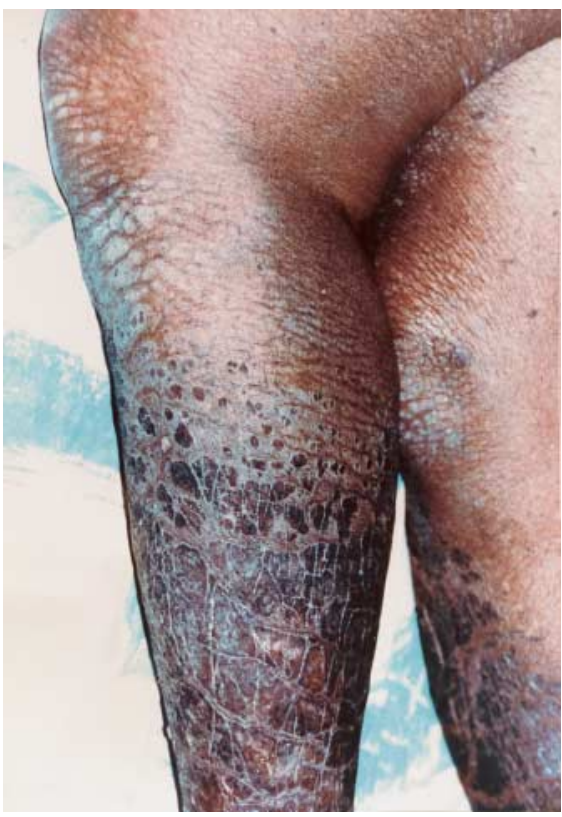

Figure 3 Severe icthyosis in same patient.

There are more males affected by HTLV-l associated lymphoma/leukaemia in our study, with a male to female ratio of 1.5:1.

\section{Tropical spastic paraparesis/HTLV-1 associated myelopathy}

Twelve cases of TSP/HAM were identified and made up 38.7\% of all paraparesis/paraplegia screened for HTLV-1. The mean age of presentation was 60 years. TSP/HAM is usually associated with infections acquired later in life. There were more females affected by TSP/HAM with a male to female ratio of $1: 2$. This is consistent with higher female than male prevalence in TSP/HAM. ${ }^{20}$ Six patients had the classical TSP/HAM with hypertonic paraparesis/paraplegia associated with exaggerated deep tendon reflexes, while six other patients had acute onset of flaccid paralysis.

\section{Ectoparasites and endoparasites}

Admission for ectoparasites and endoparasites was the most predominant associated disease occurring in $40.9 \%$ of cases. There were 17 cases of hyperinfective strongyloidiasis, one case with mild gastrointestinal symptoms, and five cases of crusted (Norwegian) scabies. The association between invasive or hyperinfective strongyloidiasis, crusted scabies, and HTLV-1 is well described by several authors. ${ }^{21-25}$ We also observed two cases each of intestinal giardiasis and hookworm infestation. One patient with hookworm had severe iron deficiency anaemia with a haemoglobin concentration of $36 \mathrm{~g} / \mathrm{l}$. Robinson et al in Jamaica found an increased prevalence of Giardia lamblia in HTLV-1 carriers (9.1\%) when compared with HTLV-1 seronegative patients $(3.5 \%){ }^{26}$

\section{HIV/AIDS}

There were three HIV seropositive patients out of 49 HTLV-1 seropositive cases of whom two had AIDS. One patient with severe wasting died from rapidly progressive pneumonia with chest radiography findings of bilateral interstitial pneumonitis suggestive of Pneumocystis carinii pneumonia, while the other had extensive tinea capitis and later died from lobar pneumonia.

Some authors have suggested that coinfection of HTLV-1 and HIV can accelerate progression of HIV to AIDS. ${ }^{27}$

The exact mechanisms by which HTLV-l causes diseases is not conclusively known. The tax gene products of HTLV-1 induces expression of interleukin-2, interleukin-2 receptors, and other transcription factors and may lead to leukaemia/ lymphoma. The mechanism of TSP/HAM may involve myelin damage by cytotoxic T-cell directed against HTLV-1 in tissues, damage by cytokines, and neutralising antibodies directed against HTLV-1 infected cells.

Immune response to the virus may explain inflammatory diseases associated with HTLV- 1 . Low levels of IgE and IgA are found in asymptomatic HTLV-1 carriers. ${ }^{28}{ }^{29}$ This may result in hyperparasitaemia especially in strongyloides and scabies infestation as observed in our study.

We have documented both infective and non-infective diseases associated with HTLV-1 in Dominica. Routine blood screening in blood transfusion services is the right step in endemic regions and in immigrants from such regions. Further efforts should be made at intensifying both physician and public awareness on HTLV-1 associated diseases.

\section{Authors' affiliations}

O Adedayo, G Grell, Department of Medicine, Princess Margare Hospital and Ross University School of Medicine, Dominica P Bellot, Department of Pathology

\section{REFERENCES}

1 Poiesz BJ, Ruscetti FW, Gazder AF, et al. Detection and isolation of type $C$ retrovirus particles from fresh and cultured lymphocytes of a patient with cutaneous T-cell lymphoma. Proc Natl Acad Sci U S A 1980;77:7415-19.

2 de The G, Bomford R. An HTLV-1 vaccine: why, how, for whom? AIDS Res Hum Retroviruses 1993:9:381-6.

3 Mueller N, Okayama A, Stuver S, et al. Findings from the Miyazaki cohort study. J Acquir Immune Defic Syndr Hum Retrovirol 1996;13(supp 1):S2-7.

4 Figueroa JP. Heterosexual transmission of HTLV-1; epidemiological aspects. WI Med J 1996:45:4-8.

5 Uchiyama T, Yodor J, Sagawa K, et al. Adult T-cell leukemia: clinical and hematological features of 16 cases. Blood 1977:50:481-92.

6 Gessain A, Barin F, Vernant JC, et al. Antibodies to human T-lymphotropic virus type- 1 in patients with tropical spastic paraparesis. Lancet 1985;ii:407-10.

7 Osame M, Usuku K, Izumo S, et al. HTLV-1 associated myelopathy, a new clinical entity. Lancet 1986;i:1031-2.

8 Mochizuki M, Tajima K, Watanabe T, et al. Human T-lymphotropic virus type 1 uveitis. Br J Ophthalmol 1994;78:149-54.

9 la Grenade L, Hanchard B, Fletcher V, et al. Infective dermatitis of Jamaican children: a marker for HTLV-1 infection. Lancet 1990;336:1345-7

10 Morgan $\mathrm{O}$ st C, Rodgers-Johnson P, Mora C, et al. HTLV-1 and polymyositis in Jamaica. Lancet 1989:ii: $1184-7$.

11 Terada K, Katamine S, Eguchi K, et al. Prevalence of serum and salivary antibodies to HTLV-1 in Sjogren's syndrome. Lancet 1994;344:1 $116-$ 19.

12 Barton EN, St C Morgan, Smikle MF, et al. Seroprevalence of HTLV-1 in chronic disease patients in Jamaica. Trans $R$ Soc Trop Med Hyg 1994:88:410-11.

13 Sato K, Maruyama I, Maruyama Y, et al. Arthritis in patients infected with human T-lymphotropic virus type-1. Clinical and immuno-pathological features. Arthritis Rheum 1991;34:717-21. 
14 Marsh BJ. Infections complications of human T-cell leukemia/lymphoma virus type 1 infection. Clin Infect Dis 1996:23:138-45.

15 Cleghorn FR, Manns R, Falk R, et al. Effect of human T-lymphotropic virus type- 1 infection on non-Hodgkin's lymphoma incidence. J Natl Cancer Inst 1995;87:1009-14.

16 Maloney EM, Cleghorn FR, Morgan OS, et al. Incidence of HTLV-1 associated myelopathy/tropical spastic paraparesis (HAM/TSP) in Jamaica and Trinidad. J Acquir Immune Defic Syndr Hum Retroviral 1998;17:167-70.

17 Uchiyama T. Human T-cell leukemia virus type 1 (HTLV-1) and human diseases. Annu Rev Immunol 1997;15:15-37.

18 Hanchard B. Adult T-cell leukemia/lymphoma in Jamaica 1986-1995. J Acquir Immune Defic Syndr Hum Retrovirol 1996:13:520-5.

19 Kamihira S, Yamada Y, Ikeda S, et al. Risk of adult T-cell leukemia developing in individuals with HTLV-1 infection. Leuk Lymphoma 1992;6:437-9

20 Centers for Disease Control and Prevention and the USHS Working Group. Guidelines for counseling of persons infected with human T-lymphotropic virus type (HTLV-1) and type 11 (HTLV-1). Ann Intern Med 1993;1 18:448-54.

21 Brosset C, Hovette P, Raphenon G, et al. HTLV-1 and co-infections. Med Trop (Mars) 1991;51:399-406.
22 Neisson-Vernant C, Edouard A. Malignant strongyloidiasis and the HTLV-1 virus. Rev Pract 1990:40:2127-8.

23 Adedayo AO, Grell GAC, Bellot P. Fatal strongyloidiasis associated with human T-cell lymphotropic virus type- 1 infection. Am J Trop Med Hyg 2001;65:650-1.

24 Mollison LC, Los T, Marning G. HTLV-1 and scabies an Australian aborigines (letter). Lancet 1993;341:1281-2.

25 Del Guidice P. Scabies in HTLV- 1 seropositive patients (letter). J Am Acad Dermatol 1997;36:134-5.

26 Robinson RD, Murphy EL, Wilks RJ, et al. Gastrointestinal parasitic infection in healthy Jamaican carriers of HTLV-1. J Trop Med Hyg 1991:94:411-15.

27 Pierik LT, Murphy EL. The clinical significance of HTLV-1 and HTLV- 11 infection in the AIDS epidemic. AIDS Clin Rev 1991: 39-57.

28 Matsumoto T, Miike T, Mizoguchi K, et al. Decreased serum levels of $\lg E$ and $\lg E$ binding factors in individuals infected with HTLV-1. Clin Exp Immunol 1990;81:207-11.

29 Newton RC, Limpuangthip P, Greenberg S, et al. Strongyloides stercoralis infection in a carrier of HTLV-1 virus with evidence of selective immunosuppression. Am J Med 1992;92:202-8.

\section{BENCH $>$ PRESS}

\section{New PMJ online submission and review system}

am pleased to inform authors and reviewers of Postgraduate Medical Journal's new online submission and review system. Bench > Press is a fully integrated electronic system which uses the internet to allow rapid and efficient submission of manuscripts, and the entire peer review process to be conducted online. Authors can submit their manuscript in any standard word processing software. Graphic formats acceptable are: .jpeg, .tiff, .gif, and .eps. Text and graphic files are automatically converted to PDF for ease of distribution and reviewing purposes. Authors are asked to approve their submission before it formally enters the reviewing process.

To access the system click on "SUBMITTING YOUR MANUSCRIPT" on the PMJ homepage: http://www.postgradmedj.com/ or you can access Bench>Press directly at http://submitpmj.bmjjournals.com/.

We are very excited with this new development and we would encourage authors and reviewers to use the online system where possible. It really is simple to use and should be a big improvement on the current peer review process. Full instructions can be found on Bench>Press and PMJ online. Please contact Natalie Davies, Project Manager, ndavies@bmjgroup.com for further information.

\section{Pre-register with the system}

We would be grateful if all $P M J$ authors and reviewers pre-registered with the system. This will give you the opportunity to update your contact and expertise data, allowing us to provide you with a more efficient service.

\section{Instructions for registering}

1. Enter http://submit-pmj.bmjjournals.com.

2. Click on "Create a new account" in the upper left hand side of the Bench>Press

homepage.

3. Enter your email address in the space provided.

4. Choose a password for yourself and enter it in the spaces provided

5. Complete the question of your choice to be used in the event you cannot remember

your password at a later time (this will be needed if you forget your password).

6. Click on the "Complete step l" button at the bottom of the screen.

7. Check the email account you registered under. An email will be sent to you with

a verification number and URL.

8. Once you receive the email, copy the verification number and click on the URL

hyperlink. Enter the verification number in the relevant field. Click on "Verify

me". This is for security reasons and to check that your account is not being used fraudulently.

9 . Enter/amend your contact information, and update your expertise data. 